\title{
CS-29 -Acción tutorial a alumnos étnico indígenas de la Universidad Tecnológica del Usumacinta, una alternativa de inclusión social y educativa
}

\author{
Tutorial action to indigenous ethnic students of the Universidad Tecnoló- \\ gica del Usumacinta, an alternative of social and educational inclusion
}

\author{
Victor H. Virgilio Méndez ${ }^{1 *}$, Martín G. Martinez Valdés ${ }^{2}$, Mario J. Martín Ruiz ${ }^{3}$ \\ 1,2 División Académica de Negocios y TIC, Universidad Tecnológica del Usumacinta, México, \\ ${ }^{3}$ División Académica de Tecnologías, Universidad Tecnológica Metropolitana, México.
}

*Autor a quien se dirige la correspondencia: victor.hugo.virgilio@gmail.com

\section{Resumen}

$\mathrm{E}$ siguiente trabajo está enfocado en el uso de las tutorías como herramienta de inclusión social educativa a alumnos étnico indígenas pertenecientes al periodo 2015-2016 dentro de la Universidad Tecnológica del Usumacinta a través de la programación de un horario de atención R-DDA-22 y de realizar un diagnóstico de las necesidades de los alumnos a través del formato R-DDA-19 con el objeto de comprender y describir los fenómenos de inserción e interculturalidad a los que se enfrentan los jóvenes universitarios provenientes de dichos grupos así como la manera en que los resuelven durante su estancia en esta institución, la cual forma técnicos superiores universitarios, ingenieros y licenciados en diversas especialidades. Aunque el origen étnico no es una condición de fracaso escolar, los estudiantes indígenas sí se enfrentan a condiciones adversas tales como la soledad o la discriminación. Condiciones que les obligan a poner en práctica una serie de tácticas y estrategias que les permitirán terminar exitosamente sus estudios, así como reivindicar orgullosamente su origen étnico.

Palabras claves: Étnico indígena, inclusión, educación, entorno empresarial, tutorías

\section{Abstract}

$\mathrm{T}$ he following work is focused on the use of tutoring as an educational social inclusion tool for indigenous ethnic students from the period 2015 - 2016 within the Technological University of Usumacinta through the programming of an R-DDA-22 service schedule and to make a diagnosis of the needs of the students through the format R-DDA-19 in order to understand and describe the phenomena of insertion and interculturality that are faced by young university students from these groups as well as the way in which they resolve during their stay in this institution, which forms university technicians, engineers and graduates in various specialties. Although ethnicity is not a condition of school failure, indigenous students do face adverse conditions such as loneliness or discrimination. Conditions that force them to put into practice a series of tactics and strategies that will enable them to successfully complete their studies, as well as to proudly claim their ethnic origin.

Key words: Indigenous ethnic inclusion, education, business environment, tutorials 